DOI: https://doi.org/10.47405/mjssh.v6i8.942

\begin{tabular}{|c|c|}
\hline & Malaysian Journal of Social Sciences and Humanities (MJSSH) \\
\hline Malaysian Journal of & Volume 6, Issue 8, August 2021 \\
\hline (Mulus SSH & e-ISSN : 2504-8562 \\
\hline & $\begin{array}{l}\text { Journal home page: } \\
\text { www.msocialsciences.com }\end{array}$ \\
\hline
\end{tabular}

\title{
Keberkesanan Kaedah Pengajaran Needham, STAD dan Konvensional Berpandukan Modul Pendidikan Kesenian Terhadap Hasil Kerja Seni dan Minat Murid Sekolah Rendah
}

\author{
Othaya Kumaran Kandasamy, Al-Amin Mydin , Abdul Ghani Kanesan¹, Shaik Abdul Malik \\ Mohamed Ismail ${ }^{1}$ \\ 1Pusat Pengajian Ilmu Pendidikan, Universiti Sains Malaysia (USM)
}

Correspondence: Othaya kumaran Kandasamy (othayausm31@student.usm.my)

\begin{abstract}
Abstrak
Kajian ini bertujuan untuk mengukur keberkesanan kaedah pengajaran Needham, STAD (Student Team Achievement Division) dan Konvensional berpandukan Modul Pendidikan Kesenian tahun empat terhadap pencapaian hasil kerja seni dan minat murid tahun empat di Sekolah Jenis Kebangsaan Tamil (SJKT). Kajian ini menggunakan reka bentuk kaedah kuasi eksperimen dengan membahagikan kepada tiga kumpulan. Kumpulan eksperimen 1 diajar dengan menggunakan kaedah pengajaran model Needham. Kumpulan eksperimen 2 diajar dengan menggunakan kaedah pengajaran model STAD. Manakala kumpulan kawalan pula diajar dengan menggunakan kaedah konvensional. Ketiga-tiga kumpulan ini diajar berpandukan Modul Pendidikan Kesenian tahun empat. Kajian ini melibatkan 92 orang murid tahun empat dari tiga buah Sekolah Jenis Kebangsaan Tamil di daerah Kuala Muda, Yan negeri Kedah. Kajian ini dijalankan selama lapan minggu. Instrumen yang diguna pakai dalam kajian ini ialah rancangan pengajaran model Needham, model STAD dan konvensional. Selain itu, ujian pra, ujian pasca dan soal selidik minat juga digunakan. Data kajian ini dianalisis dengan menggunakan ujian ANCOVA dan MANCOVA. Dapatan kajian ini menunjukkan bahawa kumpulan eksperimen 1 yang diajar dengan menggunakan kaedah pengajaran Needham menunjukkan peningkatan min skor pencapaian hasil kerja seni secara signifikan berbanding dengan kumpulan eksperimen 2 yang diajar dengan menggunakan kaedah pengajaran model STAD dan kawalan yang diajar dengan menggunakan kaedah pengajaran konvensional. Selain itu, minat murid kumpulan eksperimen 1 terhadap mata pelajaran pendidikan kesenian menunjukkan min skor yang lebih tinggi berbanding dengan kumpulankumpulan lain. Akhir sekali, kajian ini memberikan implikasi yang jelas terhadap peningkatan pencapaian hasil kerja seni dan minat murid tahun empat di SJKT dalam mata pelajaran pendidikan kesenian.
\end{abstract}

Kata kunci: pendidikan kesenian, eksperimen, model STAD, model Needham

\section{The Effectiveness of Needham, STAD and Conventional Teaching Methods Based On The Art Education Modules on Art Works and Interests of Primary School Students}

\author{
Abstract \\ This study aims to measure the effectiveness of Needham, STAD (Student Team Achievement Division) \\ and Conventional teaching methods based on the fourth year Arts Education Module on the
}


achievement of art work and interest of fourth year students in Tamil National Type Schools (SJKT). This study uses a quasi-experimental method design by dividing into three groups. Experimental group 1 was taught using the Needham model teaching method. Experimental group 2 was taught using the STAD model teaching method. While the control group was taught using conventional methods. All three groups are taught based on the fourth year Arts Education Module. This study involved 92 fourth year students from three Tamil National Type Schools in Kuala Muda district, Yan state of Kedah. The study was conducted for eight weeks. The instruments used in this study were Needham model lesson plan, STAD model and conventional. In addition, pre -test, post -test and interest questionnaire were also used. The data of this study were analyzed using ANCOVA and MANCOVA tests. The findings of this study showed that experimental group 1 taught using Needham teaching method showed a significant increase in mean achievement score of artwork compared to experimental group 2 taught using STAD model teaching method and control taught using conventional teaching method. In addition, the interest of students in experimental group 1 towards the subject of art education showed a higher mean score compared to the other groups. Finally, this study provides clear implications on the improvement of the achievement of works of art and the interest of fourth year students in SJKT in the subject of art education.

Keywords: art Education, experiments, STAD model, Needham model

\section{Pengenalan}

Pendidikan Kesenian merupakan komponen penting dalam kurikulum kebangsaan di peringkat sekolah rendah. Mata pelajaran ini menyumbang kepada usaha Kementerian Pendidikan Malaysia untuk membentuk kemenjadian murid yang holistik dan seimbang selaras dengan Falsafah Pendidikan Kebangsaan. Pendidikan Kesenian dibina dengan memberi penekanan kepada empat modul kurikulum iaitu Bahasa Seni, Kemahiran Seni, Kreativiti dan Inovasi Seni, serta Apresiasi Seni. Kandungan modul tersebut adalah saling melengkapi supaya murid dapat mengaplikasikan pengetahuan, kemahiran dan nilai yang dipelajari daripada satu modul kepada modul yang lain. Pendidikan Kesenian memberikan pengalaman yang unik kepada murid untuk mengeksplorasi potensi diri, membina kemahiran generik dan sosial bagi melahirkan insan yang kreatif dan inovatif (Kurikulum standard sekolah rendah, 2018).

Penguasaan Standard Kandungan (SK) dan Standard Pembelajaran (SP) dalam mata pelajaran Pendidikan Kesenian menyumbang kepada pemerolehan Kemahiran Abad Ke-21 dalam kalangan murid. Pelbagai pendekatan boleh digunakan dalam merangka pengajaran dan pembelajaran bagi mencapai standard pembelajaran Pendidikan Kesenian. Antara pendekatan yang boleh digunakan dalam Pendidikan Kesenian adalah seperti pembelajaran berasaskan inkuiri; pembelajaran berasaskan masalah; pembelajaran berasaskan modul; pendekatan bertema dan pendekatan antara disiplin. Bagi mencapai matlamat ini, guru memainkan peranan yang penting dalam mempelbagaikan kaedah pengajaran dan pembelajaran (Bavani \& Zamri Mahamod, 2017). Dalam pengajaran dan pembelajaran Pendidikan Kesenian, penggunaan kaedah pengajaran dan pembelajaran yang sesuai oleh guru secara langsung meningkatkan pemahaman murid serta menarik minat murid. Salah satu kaedah penting yang boleh meningkatkan proses pengajaran dan pembelajaran yang berkesan ialah kaedah pengajaran Needham dan kaedah pengajaran STAD (Student Team Achievement Division). Kaedah pengajaran Needham dan STAD merupakan kaedah berpusatkan murid yang memberi peluang kepada murid untuk menyelesaikan masalah dalam kumpulan (Malar, 2013).

Kebanyakan kajian menunjukkan, murid tidak berminat untuk mempelajari mata pelajaran Pendidikan Kesenian kerana kaedah pengajaran guru yang kurang berkesan dan membosankan. Pengajaran dan pembelajaran guru yang tidak berinovasi menyebabkan murid merasakan mata pelajaran Pendidikan Kesenian tidak mencabar. Kaedah pengajaran secara konvensional tidak begitu menarik minat murid. Mereka kurang aktif dan sukar memberikan tumpuan dalam mengikuti aktiviti pengajaran dan pembelajaran Pendidikan Kesenian. Guru-guru yang mengajar Pendidikan Kesenian tidak seharusnya terlalu bergantung kepada penggunaan buku teks sahaja dalam proses pengajaran dan pembelajaran. 
Oleh itu, pengajaran dan pembelajaran berbentuk inovasi diperlukan bagi menjadikan mata pelajaran Pendidikan Kesenian lebih menarik dan diminati oleh murid.

\section{Tujuan Kajian}

i. Mengenal pasti perbezaan yang signifikan skor pencapaian hasil kerja seni antara Kumpulan Eksperimen 1 yang diajar dengan menggunakan kaedah Needham, Kumpulan Eksperimen 2 yang diajar dengan menggunakan kaedah STAD dan Kumpulan 3 yang diajar dengan menggunakan kaedah konvensional berpandukan Modul Pendidikan Kesenian Tahun 4.

ii. Mengenal pasti perbezaan signifikan skor minat murid antara Kumpulan Eksperimen 1 yang diajar dengan menggunakan kaedah Needham, Kumpulan Eksperimen 2 yang diajar dengan menggunakan kaedah STAD dan Kumpulan 3 yang diajar dengan menggunakan kaedah konvensional berpandukan Modul Pendidikan Kesenian Tahun 4.

\section{Sorotan Literatur}

\section{Konsep Model Needham}

Model Konstruktivisme Lima Fasa Needham yang digunakan dalam kajian ini terdiri daripada lima fasa. Model ini diperkenalkan oleh Richard Needham pada tahun 1987. Model ini memberikan peluang kepada murid untuk mengaitkan pembelajaran terdahulu dengan pembelajaran terbaharu. (1) Fasa pertama ialah Fasa Orientasi iaitu menyediakan suasana pembelajaran yang dapat merangsang minat pelajar terhadap pembelajaran. (2) Fasa kedua ialah Fasa Pencetus Idea iaitu menjalankan aktiviti perbincangan bagi mengumpul idea dalam kalangan ahli kumpulan. Pelajar boleh berinteraksi di antara satu sama lain dalam kumpulan. (3) Seterusnya fasa ketiga ialah Fasa Penstrukturan Semula Idea iaitu membolehkan murid membina struktur pengetahuan sendiri berdasarkan idea mereka sendiri untuk menghasilkan pengetahuan yang lebih berkesan. (4) Manakala fasa keempat pula ialah Fasa Aplikasi Idea iaitu murid mengaplikasikan pengetahuan dari fasa-fasa sebelumnya dengan menyelesaikan masalah dalam situasi pembelajaran. (5) Akhir sekali fasa kelima ialah Fasa Refleksi iaitu merenung kembali proses pembelajaran yang telah mereka jalani yang menyebabkan perubahan idea mereka (Arihasnida et al., 2020).

\section{Konsep Model STAD}

Kaedah koperatif adalah salah satu strategi pengajaran inovatif (Chan, 2014). Kaedah koperatif mengambil kira aspek kognitif, tingkah laku, emosi dan sosial pelajar. Tahap pembelajaran dalam kaedah koperatif bukan sahaja untuk diri sendiri, tetapi juga untuk rakan-rakan yang lain. Lima unsur asas dalam pembelajaran koperatif ialah saling bergantung di antara satu sama lain secara positif; saling berinteraksi secara bersemuka; akauntabiliti individu atas pembelajaran diri sendiri; kemahiran kolobarasi; pemprosesan kumpulan (Vaughan, 2002). Terdapat beberapa jenis strategi yang boleh digunakan dalam pembelajaran koperatif. Di antaranya ialah (1) penyiasatan berkelompok (Group Investigation); (2) Student Team Achievement Division (STAD); (3) Jigsaw; (4) Team-Accelerated Instruction (TAI); (5) Team Games Tournament (TGT). Dalam kajian ini kaedah pembelajaran model STAD (Student Team Achievement Division) digunakan. Ciri-ciri penting kaedah pembelajaran model STAD ialah pembentangan kumpulan, demonstrasi dan kuiz interaktif individu. Selain itu, markah kumpulan pula dinilai berdasarkan pembentangan kumpulan dan kuiz interaktif individu. Kumpulan yang menang akan diberi ganjaran dan pujian (Malar, 2013).

\section{Teori Berkaitan}

Teori konstruktivisme menyatakan bahawa murid dapat membina sendiri makna sesuatu pengetahuan berasaskan pengetahuan sedia ada mereka. Kajian ini menggunakan Model Konstruktivisme Lima Fasa Needham. Pengajaran dan pembelajaran secara konstruktivisme menggalakkan murid-murid 
mencipta penyelesaian mereka sendiri bertolak daripada teori pembelajaran behaviorisme kepada kognitivisme dan seterusnya konstruktivisme. Teori ini memberikan panduan kepada para guru untuk mewujudkan suasana persekitaran yang membolehkan pelajar memainkan peranan yang aktif di dalam proses pembelajaran mereka (Arihasnida et al., 2020). Manakala kaedah pembelajaran koperatif boleh digunakan dalam pelbagai kumpulan umur tetapi kaedahnya sangat popular di sekolah rendah (Robert, 2015). Salah satu kaedah pembelajaran koperatif ialah kaedah pembelajaran koperatif model STAD. Kaedah ini berpusatkan murid dan berasaskan kepada teori konstruktivisme sosial yang dibentuk oleh Vygotsky. Kaedah ini menekankan kerjasama dalam kalangan murid dan menggalakkan pembelajaran berkumpulan. Murid akan bekerja dalam kumpulan kecil dan bekerjasama untuk melengkapkan tugasan, berkongsi idea serta saling membantu untuk menyelesaikan masalah. Semua ahli kumpulan perlu melibatkan diri secara aktif dan guru pula berperanan sebagai pemudahcara.

\section{Tinjauan Kajian Berkaitan}

Hasil kajian Syamsul (2011) menunjukkan bahawa murid bermotivasi dan berminat semasa proses pembelajaran yang menggunakan kaedah pengajaran Lima Fasa Needham. Strategi Lima Fasa Needham membolehkan murid melibatkan diri secara aktif dalam pembelajaran. Selain itu, murid juga menunjukkan kesedaran diri, bertanggungjawab dan berdikari yang mendorong pelajar belajar dengan lebih baik. Kaedah pengajaran Lima Fasa Needham memberikan kesan yang baik terhadap potensi pembelajaran murid. Hal ini adalah kerana pelajar digalakkan bekerja dalam kumpulan. Mereka didedahkan dengan tiga domin pembelajaran iaitu kognitif, afektif dan psikomotor. Selain itu, kaedah pengajaran Lima Fasa Needham adalah berpusatkan murid dan meningkatkan motivasi belajar dalam kalangan murid.

Kaedah pengajaran model STAD juga menggalakkan setiap ahli kumpulan berkomunikasi antara satu sama lain untuk menyatakan pendapat, idea ataupun untuk mendapatkan maklumat. Selain itu, kaedah pengajaran $S T A D$ juga merupakan satu aktiviti bekerjasama antara kumpulan bagi melengkapkan tugasan kumpulan dan menjawab soalan kuiz secara spontan. Kuiz secara spontan memberi peluang kepada murid untuk menilai secara berperingkat penguasaan murid dalam mata pelajaran yang diajar (Malar, 2013). Menurut Altun (2015) pembelajaran koperatif tidak boleh diajar secara lisan. Malah pembelajaran koperatif memerlukan penglibatan murid bekerja bersama-sama dalam kumpulan, membangunkan satu produk dan menilai produk yang dihasilkan. Kajian-kajian lepas menunjukkan pembelajaran koperatif boleh digunakan untuk meningkatkan pencapaian murid (Vaughan, 2002; Iyer, 2013).

Bavani dan Zamri (2017) dalam kajiannya membuktikan bahawa pembelajaran koperatif ialah satu pendekatan pengajaran yang dapat mengurangkan masalah disiplin yang mengganggu pembelajaran di bilik darjah. Selain itu, strategi-strategi pembelajaran koperatif bukan sahaja dapat menarik minat murid tetapi dapat melibatkan murid secara aktif dalam pembelajaran. Kajian Ocampo dan BascosOcampo (2015) juga membuktikan bahawa murid yang didedahkan kepada kaedah pembelajaran koperatif model STAD telah memperbaiki sikap murid dan pencapaian terhadap mata pelajaran Fizik. Selain itu, kajian Zainun, Zanaton dan Norziah (2013) juga menunjukkan pembelajaran koperatif model STAD memberikan kesan yang baik dalam menukar sikap pelajar terhadap matematik.

Dapatan kajian Van Wyk (2012) juga menunjukkan bahawa pembelajaran koperatif model STAD, dapat membentuk sikap positif; peningkatan pencapaian dan motivasi murid dalam mata pelajaran ekonomi. Selain itu, kajian Tran (2014) turut menegaskan bahawa pembelajaran koperatif memberikan kesan positif terhadap pencapaian murid dan ketekalan pengetahuan. Di samping itu, kajiannya menunjukkan bahawa pembelajaran berdasarkan tugasan dan penglibatan murid sendiri dalam proses pembelajaran koperatif mengekalkan pencapaian murid walaupun berlaku kelewatan dalam pengujian. Kajian Gull dan Shehzad (2015) dalam sains sosial juga menyokong dapatan kajian lain yang menyatakan bahawa pencapaian murid meningkat dalam aktiviti pembelajaran koperatif. Tahap motivasi murid dalam kajiannya turut meningkat apabila mereka saling membantu dan bekerja dalam kumpulan. Keseronokan bekerja dalam kumpulan dan kaedah pembelajaran yang berbeza berbanding dengan kaedah konvensional juga turut membantu meningkatkan pencapaian serta mengubah minat murid terhadap pembelajaran. 


\section{Pembinaan Modul Pendidikan Kesenian Tahun Empat}

Modul Pendidikan Kesenian tahun empat dibina berasaskan Model ADDIE yang berpandukan pada Dokumen Standard Kurikulum dan Pentaksiran (DSKP), Pendidikan Kesenian Tahun 4. Model ADDIE dikembangkan oleh Dick dan Carry (1996). Model ADDIE merupakan model reka bentuk yang berfungsi sebagai garis panduan ke arah penghasilan bahan-bahan pengajaran dan pembelajaran. Model ADDIE merupakan model pengajaran yang sering digunakan sebagai asas kepada model-model reka bentuk pengajaran dan pembelajaran. Tujuan model ini direka bentuk adalah untuk menghasilkan rancangan pengajaran dan bahan pembelajaran agar penyampaian sesuatu pengajaran itu akan menjadi lebih efektif dan efisien. Berdasarkan model ADDIE, terdapat lima fasa dalam proses menghasilkan modul ini. Modul Pendidikan Kesenian tahun 4 merupakan modul yang dibina bagi membantu murid memahami isi kandungan mata pelajaran Pendidikan Kesenian. Modul ini dihasilkan dalam bentuk media cetak yang mengandungi kombinasi nota dan latihan yang dipecahkan mengikut sub topik serta objektif pengajaran dan pembelajaran yang ingin dicapai. Panduan penghasilan bahan dipersembahkan dalam bentuk turutan bergambar berwarna. Hal ini bertujuan untuk menarik minat murid dan memudahkan murid memahami isi kandungan pelajaran tanpa bantuan guru.

\section{Metod Kajian}

Reka bentuk kajian ini mengaplikasikan kaedah kuasi eksperimen. Kajian ini dijalankan selama lapan minggu. Subjek kajian terdiri daripada 92 orang murid tahun empat dari tiga buah sekolah jenis kebangsaan Tamil di daerah Kuala Muda, Yan Kedah. Subjek seramai 32 orang adalah daripada sekolah A dipilih sebagai kumpulan eksperimen 1. Manakala subjek seramai 32 orang daripada sekolah B dipilih sebagai kumpulan eksperimen 2 dan subjek seramai 30 orang daripada sekolah C dipilih sebagai kumpulan kawalan. Setiap sekolah mewakili satu kumpulan kajian agar pengajaran yang diberikan kepada satu kumpulan tidak mempengaruhi kumpulan lain. Subjek daripada ketiga-tiga kumpulan merupakan murid yang mempunyai tahap pencapaian yang hampir sama. Kumpulan Eksperimen 1 diajar dengan menggunakan kaedah Needham, Kumpulan Eksperimen 2 yang diajar dengan menggunakan kaedah $S T A D$ dan Kumpulan 3 diajar dengan menggunakan kaedah konvensional berpandukan Modul Pendidikan Kesenian Tahun 4.

Dalam kajian ini, dua jenis instrumen telah digunakan. Iaitu soalan pra ujian dan pasca ujian bagi mengukur pencapaian hasil kerja seni. Selain itu, soal selidik yang adaptasi dari soal selidik Attitude scale for art experienced in school (ASAES)(Pavlou \& Kambouri, 2007) digunakan untuk mengukur minat murid terhadap mata pelajaran Pendidikan Kesenian. Kesahan pra ujian dan pasca ujian dilakukan oleh ketua panitia yang berpengalaman. Kesahan Modul Pendidikan Kesenian dan soal selidik minat pula dilakukan oleh dua orang pensyarah dari unit Pendidikan Kesenian, IPGK. Kajian rintis telah dijalankan untuk mengukur kebolehpercayaan soalan pra ujian dan pasca ujian serta item soal selidik minat. Hal ini adalah untuk memastikan murid dapat memahami segala arahan dan kehendak soalan.

Penyelidik telah melatih guru yang mengajar kumpulan eksperimen 1 tentang langkah-langkah kaedah pengajaran Needham dan eksperimen 2 tentang langkah-langkah kaedah pengajaran STAD berpandukan Modul Pendidikan Kesenian tahun empat. Guru kumpulan kawalan pula mengajar secara konvensional dengan menggunakan Modul Pendidikan Kesenian tahun empat. Guru-guru dibekalkan dengan tajuk pengajaran, rancangan pengajaran dan pembelajaran serta bahan bantu mengajar untuk lapan minggu. Pada minggu pertama kumpulan eksperimen dan kumpulan kawalan diberikan pra ujian dan soal selidik minat. Mulai minggu kedua hingga minggu ketujuh pengajaran dan pembelajaran dijalankan seperti yang dirancangkan. Pada minggu kelapan kumpulan eksperimen 1, kumpulan eksperimen 2 dan kumpulan kawalan diberikan ujian pasca dan soal selidik minat. Sebanyak empat kali penyelidik telah mencerap pengajaran dan pembelajaran guru bagi memastikan guru-guru telah mengikut langkah-langkah pengajaran dan pembelajaran yang telah disediakan. 


\section{Hasil Kajian}

\section{Maklumat Demografi Sampel Kajian}

Subjek kajian ini terdiri daripada 92 orang murid dari tiga buah sekolah jenis kebangsaan Tamil di daerah Kuala Muda/Yan, Kedah. Kajian ini dibahagikan kepada tiga kumpulan iaitu kumpulan eksperimen 1, kumpulan eksperimen 2 dan kumpulan kawalan. Seramai 30 subjek kumpulan eksperimen 1 telah diberi rawatan menggunakan kaedah pengajaran Needham; seramai 32 subjek kumpulan eksperimen 2 telah diberi rawatan menggunakan kaedah pengajaran STAD dan seramai 30 subjek kumpulan kawalan diajar dengan menggunakan kaedah pengajaran konvensional. Jadual 1 menunjukkan keputusan statistik deskriptif demografi pelajar yang terlibat dalam kajian ini.

Jadual 1: Taburan Frekuensi dan Peratusan Subjek Kajian

\begin{tabular}{lllll}
\hline \multirow{2}{*}{ Kumpulan } & \multicolumn{2}{c}{ Jantina } & \multirow{2}{*}{ Jumlah } \\
\cline { 2 - 3 } & Lelaki & Perempuan & 30 & \\
\hline Eksperimen 1 & $13(43.3 \%)$ & $17(56.7 \%)$ & 32 & \\
Eksperimen 2 & $15(46.9 \%)$ & $17(53.1 \%)$ & 30 & \\
Kawalan & $14(46.7 \%)$ & $16(53.3 \%)$ & 92 & \\
\hline Jumlah & $42(45.7 \%)$ & $30(54.3 \%)$ & & \\
\hline
\end{tabular}

Jadual 1 menunjukkan seramai 13 orang pelajar (43.3\%) adalah subjek lelaki dan 17 orang pelajar (56.7\%) adalah subjek perempuan terlibat dalam rawatan kumpulan eksperimen 1, seramai 15 orang pelajar (46.9\%) adalah subjek lelaki dan 17 orang pelajar (53.1\%) adalah subjek perempuan terlibat dalam rawatan kumpulan eksperimen 2, Manakala kumpulan kawalan pula terdiri daripada 14 orang pelajar $(46.7 \%)$ adalah subjek lelaki dan 16 orang pelajar (53.3\%) adalah subjek perempuan. Para pelajar yang terlibat dalam kajian ini berumur 10 tahun.

\section{Hipotesis nol kajian}

H01 :Tidak terdapat perbezaan yang signifikan skor pencapaian hasil kerja seni antara Kumpulan Eksperimen 1 yang diajar dengan menggunakan kaedah Needham, Kumpulan Eksperimen 2 yang diajar dengan menggunakan kaedah STAD dan Kumpulan 3 yang diajar dengan menggunakan kaedah konvensional berpandukan Modul Pendidikan Kesenian Tahun 4.

Penggunaan ujian ANCOVA adalah tertakluk kepada beberapa syarat. Antaranya ialah skor-skor variabel perlu bertaburan secara normal dalam semua kumpulan bagi melakukan perbandingan. Selain itu, kumpulan-kumpulan tersebut juga perlu mempunyai nilai varians yang hampir sama.

Pengujian hipotesis 1 telah dilakukan dengan menggunakan analisis ANCOVA dengan menjadikan skor min pra ujian pencapaian keseluruhan terhadap pembelajaran Pendidikan Kesenian sebagai kovariat manakala skor min ujian pasca pencapaian hasil kerja seni pula dijadikan sebagai pemboleh ubah bersandar. Berikut adalah dapatan deskriptif perbezaan skor min pencapaian ujian pasca terhadap pembelajaran Pendidikan Kesenian.

Jadual 2: Dapatan Skor Min Pencapaian Ujian Pasca Terhadap Pembelajaran Pendidikan Kesenian Mengikut Kumpulan

\begin{tabular}{llll}
\hline Kumpulan & Min & Sisihan Piawai & N \\
\hline Eksperimen 1 & 27.30 & 1.12 & 30 \\
Eksperimen 2 & 23.25 & 2.11 & 32 \\
Kawalan & 17.90 & 3.39 & 30 \\
\hline
\end{tabular}


Eksperimen 1 = Pengajaran Berasaskan Kaedah Needham

Eksperimen 2 = Pengajaran Berasaskan Kaedah STAD

Kawalan $=$ Pengajaran Konvensional

Dapatan dari Jadual 2 di atas menunjukkan bahawa skor min pencapaian pasca ujian terhadap pembelajaran Pendidikan Kesenian yang paling tinggi diperoleh kumpulan Eksperimen 1 (Min = 27.30, sisihan piawai $=1.12)$. Diikuti oleh kumpulan Eksperimen $2($ Min $=23.25$, sisihan piawai $=$ 2.11) dan akhir sekali kumpulan Kawalan $($ Min $=17.90$, sisihan piawai $=3.39$ ). Dapatan ini menjelaskan bahawa terdapat peningkatan skor min pencapaian pasca ujian bagi kumpulan Eksperimen 1 berbanding Eksperimen 2 dan Kawalan, namun demikian perbezaan skor min perlu dibuktikan secara statistik, maka analisis ANCOVA telah dijalankan dan dapatan nya adalah seperti yang dipaparkan di bawah ini.

Jadual 3: Kesan Kaedah Pengajaran terhadap Pencapaian Hasil Kerja Seni Pendidikan Kesenian

\begin{tabular}{lllllll}
\hline Sumber & $\begin{array}{l}\text { Jumlah kuasa } \\
\text { dua Jenis 111 }\end{array}$ & $\begin{array}{l}\text { Min } \\
\text { KuasaDua }\end{array}$ & F & Sig. & Eta Separa kuasa dua \\
\hline $\begin{array}{l}\text { Model } \\
\text { diperbetulkan }\end{array}$ & $1394.803^{\mathrm{a}}$ & 3 & 464.934 & 91.242 & .000 & .757 \\
Pintasan & 4196.157 & 1 & 4196.157 & 823.483 & .000 & .903 \\
UJIAN_PRA & 60.586 & 1 & 60.586 & 11.890 & .001 & .119 \\
Kumpulan & 1280.520 & 2 & 640.260 & 125.649 & .000 & .741 \\
$\begin{array}{l}\text { Jumlah } \\
\text { diperbetulkan }\end{array}$ & 1843.217 & 91 & & & & \\
\hline Nota: $:$ S Squared & $=.757$ (Adjusted $R$ Squared $=.748)$ & & &
\end{tabular}

Dapatan analisis ANCOVA dalam Jadual 3 di atas mengesahkan bahawa terdapat kesan utama pemboleh ubah bebas iaitu kumpulan (kaedah mengajar) terhadap pemboleh ubah bersandar pencapaian hasil kerja seni terhadap pembelajaran Pendidikan Kesenian setelah mengawal pemboleh ubah skor min pra ujian $(\mathrm{F}(2,91)=125.65, \mathrm{p}=.00)$. Dapatan ini menjelaskan bahawa kaedah pengajaran telah memberikan kesan yang signifikan ke atas peningkatan skor min pencapaian Pendidikan Kesenian dan ringkasan analisis tersebut dipaparkan dalam Jadual 4 di bawah.

Jadual 4: Dapatan Perbandingan Skor Min Pencapaian terhadap Pembelajaran Pendidikan Kesenian Mengikut Pasangan Kumpulan

\begin{tabular}{llll}
\hline Kumpulan & Kumpulan & Perbezaan Min & Nilai p \\
\hline Eksperimen 1 & Eksperimen 2 & $3.802^{*}$ & .000 \\
& Kawalan & $9.219^{*}$ & .000 \\
\hline Eksperimen 2 & Eksperimen 1 & $-3.802^{*}$ & .000 \\
& Kawalan & $5.418^{*}$ & .000 \\
\hline Kawalan & Eksperimen 1 & $-9.219^{*}$ & .000 \\
& Eksperimen 2 & $-5.418^{*}$ & .000 \\
\hline
\end{tabular}

Nota:

Perbezaan sig. pada aras $\mathrm{p}<.05$

Eksperimen 1 = Pengajaran Berasaskan Kaedah Needham

Eksperimen 2 = Pengajaran Berasaskan Kaedah STAD

Kawalan $=$ Pengajaran Konvensional

Dapatan analisis perbandingan pasangan skor min antara ketiga-tiga kumpulan selepas mengawal ralat jenis 1 melalui kaedah Bonferroni ANCOVA dalam Jadual 4 di atas menunjukkan skor min pencapaian pasangan perbandingan kaedah mengajar Eksperimen 1 memperoleh perbezaan yang signifikan dengan kaedah mengajar Eksperimen 2 (perbezaan skor min pencapaian $=3.802 ; \mathrm{p}=.00$ ); dan kaedah mengajar kawalan (perbezaan skor min pencapaian $=9.219 ; \mathrm{p}=.00$ ). Dapatan ini mengukuhkan bahawa responden yang didedahkan dengan kaedah mengajar kumpulan Eksperimen 1 iaitu kaedah pengajaran berasaskan Needham memperoleh skor min pencapaian tertinggi terhadap pengajaran Pendidikan Kesenian. 
DOI: https://doi.org/10.47405/mjssh.v6i8.942

Berdasarkan kepada dapatan-dapatan analisis di atas maka kesimpulannya ialah terdapat perbezaan yang signifikan skor pencapaian keseluruhan antara kumpulan iaitu kumpulan Eksperimen 1 yang diajar dengan menggunakan kaedah Needham memperoleh peningkatan skor min keseluruhan tertinggi berbanding Kumpulan Eksperimen 2 yang diajar dengan menggunakan kaedah STAD dan Kumpulan 3 yang diajar dengan menggunakan kaedah konvensional berpandukan Modul Pendidikan Kesenian. Dengan itu hipotesis $\mathrm{H}_{01}$ adalah ditolak.

\section{Hipotesis nol kajian}

HO2 :Tidak terdapat perbezaan signifikan skor minat murid antara Kumpulan Eksperimen 1 yang diajar dengan menggunakan kaedah Needham, Kumpulan Eksperimen 2 yang diajar dengan menggunakan kaedah STAD dan Kumpulan 3 yang diajar dengan menggunakan kaedah konvensional berpandukan Modul Pendidikan Kesenian Tahun 4.

Bagi menguji hipotesis di atas, ujian statistik MANCOVA telah digunakan. Namun demikian, sebelum analisis tersebut dilakukan, dapatan analisis deskriptif skor min minat sebelum dan selepas intervensi bagi setiap kumpulan di paparkan dalam jadual 5.

Jadual 5: Dapatan Skor Min Minat Sebelum dan Selepas Intervensi Mengikut Kumpulan

\begin{tabular}{llll}
\hline & Kumpulan & Min & Sisihan Piawai \\
\hline MINAT_SEBELUM & Eksperimen 1 & 1.84 & .37 \\
& Eksperimen 2 & 2.22 & .25 \\
& Kawalan & 2.17 & .23 \\
\hline MINAT_SELEPAS & Eksperimen 1 & 4.61 & .20 \\
& Eksperimen 2 & 4.13 & .60 \\
& Kawalan & 3.60 & .20 \\
\hline
\end{tabular}

Nota:

Eksperimen 1 = Pengajaran Berasaskan Kaedah Needham

Eksperimen 2 = Pengajaran Berasaskan Kaedah STAD

Kawalan = Pengajaran Konvensional

Jadual 5 menunjukkan min skor minat murid sebelum pengajaran yang menggunakan kaedah pengajaran Needham (Kumpulan Eksperimen 1) ialah $(\mathrm{M}=1.85, \mathrm{SD}=0.371)$ manakala min skor minat murid selepas menggunakan kaedah pengajaran Needham pula adalah $(\mathrm{M}=4.61, \mathrm{SD}=0.206)$. Hal ini menunjukkan bahawa terdapat peningkatan min skor minat murid Kumpulan Eksperimen 1 adalah sebanyak 2.76. Sebaliknya min skor minat murid sebelum menggunakan Kaedah pengajaran STAD (Kumpulan Eksperimen 2) ialah $(\mathrm{M}=2.22, \mathrm{SD}=0.259)$ manakala min skor minat murid selepas menggunakan Kaedah pengajaran $S T A D$ pula adalah $(\mathrm{M}=4.14, \mathrm{SD}=0.601)$. Hal ini menunjukkan peningkatan min skor minat murid bagi kumpulan eksperimen 2 adalah sebanyak 1.92. Seterusnya min skor minat murid sebelum menggunakan Kaedah pengajaran konvensional (Kumpulan Kawalan) ialah $(\mathrm{M}=2.18, \mathrm{SD}=0.238)$ manakala min skor minat murid selepas kaedah pengajaran Konvensional adalah $(\mathrm{M}=3.60, \mathrm{SD}=0.207)$. Peningkatan min skor minat murid bagi kumpulan kawalan ialah 1.42. Kesimpulannya keputusan di atas menunjukkan bahawa peningkatan skor min minat pembelajaran Pendidikan Kesenian bagi Kumpulan Eksperimen 1 adalah lebih tinggi berbanding dengan Kumpulan Eksperimen 2 dan Kumpulan Kawalan. Bagi mengukuhkan lagi keputusan ini, maka analisis lanjutan MANCOVA dilakukan dan dapatannya dipaparkan dalam Jadual 6.

Dapatan analisis MANCOVA dalam Jadual 6 mengesahkan bahawa dalam subjek kajian, terdapat kesan utama pemboleh ubah bebas iaitu kumpulan (kaedah mengajar) terhadap pemboleh ubah bersandar minat murid terhadap pembelajaran Pendidikan Kesenian selepas intervensi $[F(2,91)$ $=49.59, \mathrm{p}=.00]$ dan sebelum intervensi $[\mathrm{F}(2,91)=14.65, \mathrm{p}=.00]$. Dapatan ini menjelaskan bahawa kaedah pengajaran telah memberikan kesan yang signifikan ke atas peningkatan min skor minat lebih tinggi selepas intervensi berbanding sebelum intervensi terhadap pembelajaran Pendidikan Kesenian. 
Berdasarkan kepada dapatan-dapatan analisis di atas maka kesimpulannya ialah terdapat perbezaan yang signifikan skor min minat terhadap Pendidikan Kesenian antara kumpulan iaitu kumpulan Eksperimen 1 yang diajar dengan menggunakan kaedah pengajaran Needham memperoleh skor min minat terhadap Pendidikan Kesenian tertinggi berbanding dengan Kumpulan Eksperimen 2 yang diajar dengan menggunakan kaedah pengajaran STAD dan Kumpulan 3 yang diajar dengan menggunakan kaedah pengajaran konvensional berpandukan Modul Pendidikan Kesenian. Berdasarkan dapatandapatan di atas maka hipotesis $\mathrm{H}_{02}$ adalah ditolak.

Jadual 6: Dapatan Analisis MANCOVA (Ujian Kesan Antara Subjek) Kaedah Pengajaran Terhadap Skor Minat Murid

\begin{tabular}{|c|c|c|c|c|c|c|}
\hline Sumber & $\begin{array}{l}\text { Pemboleh } \\
\text { ubah } \\
\text { Bersandar }\end{array}$ & $\begin{array}{l}\text { Jumlah } \\
\text { kuasa dua } \\
\text { Jenis } 111 \\
\end{array}$ & df & $\mathbf{F}$ & Sig. & $\begin{array}{l}\text { Eta separa } \\
\text { kuasa dua }\end{array}$ \\
\hline \multirow[t]{2}{*}{$\begin{array}{l}\text { Model } \\
\text { diperbetulkan }\end{array}$} & $\begin{array}{l}\text { Minat_- } \\
\text { Sebelum }\end{array}$ & $2.549^{\mathrm{a}}$ & 2 & 14.645 & .000 & .248 \\
\hline & $\begin{array}{l}\text { Minat_ } \\
\text { Selepas }\end{array}$ & $15.240^{\mathrm{b}}$ & 2 & 49.591 & .000 & .527 \\
\hline \multirow[t]{2}{*}{ Pintasan } & $\begin{array}{l}\text { Minat__ } \\
\text { Sebelum }\end{array}$ & 398.420 & 1 & 4577.633 & .000 & .981 \\
\hline & $\begin{array}{l}\text { Minat_- } \\
\text { Selepas }\end{array}$ & 1558.302 & 1 & 10141.254 & .000 & .991 \\
\hline \multirow[t]{2}{*}{ Kumpulan } & $\begin{array}{l}\text { Minat__ } \\
\text { Sebelum }\end{array}$ & 2.549 & 2 & 14.645 & .000 & .248 \\
\hline & $\begin{array}{l}\text { Minat_ } \\
\text { Selepas }\end{array}$ & 15.240 & 2 & 49.591 & .000 & .527 \\
\hline $\begin{array}{l}\text { ota: } a . R \text { Squ } \\
\text { b. } R \text { Square }\end{array}$ & $\begin{array}{l}d=.248(\text { Ad) } \\
.527 \text { (Adjust }\end{array}$ & $\begin{array}{l}\text { ed R Square } \\
\text { R Squared }=\end{array}$ & $\begin{array}{l}=.2 \\
516)\end{array}$ & & & \\
\hline
\end{tabular}

\section{Perbincangan Kajian}

Dapatan kajian menunjukkan bahawa subjek kumpulan eksperimen 1 yang diajar dengan menggunakan kaedah pengajaran Needham berpandukan Modul Pendidikan Kesenian telah memperoleh min skor pencapaian hasil kerja seni yang lebih tinggi dan signifikan berbanding dengan subjek kumpulan eksperimen 2 dan kawalan. Hasil dapatan kajian ini selari dengan dapatan kajian (Vaughan, 2002; Malar, 2013; Iyer, 2013). Selain itu, kajian ini juga menunjukkan peningkatan min skor subjek kumpulan eksperimen 1 yang diajar dengan menggunakan kaedah pengajaran Needham berpandukan Modul Pendidikan Kesenian memberikan reaksi yang lebih tinggi dalam tahap minat berbanding dengan kumpulan eksperimen 2 dan kumpulan kawalan. Hasil dapatan kajian ini menyokong dapatan kajian (Van Wyk, 2012; Zainun et al., 2013; Tran, 2014; Gull \& Shehzad, 2015; Ocampo \& Bascos-Ocampo, 2015; Bavani \& Zamri, 2017). Dapatan kajian Jasin dan Shaari (2012) juga membuktikan bahawa pendekatan pengajaran dan pembelajaran secara konstruktivisme lebih efektif berbanding pengajaran dan pembelajaran secara konvensional. Secara keseluruhan dapatan kajian ini menunjukkan bahawa penggunaan kaedah pengajaran Needham dalam mata pelajaran Pendidikan Kesenian memberikan kesan positif terhadap pencapaian hasil kerja seni dan minat murid terhadap Pendidikan Kesenian.

\section{Implikasi Kajian}

Dapatan kajian ini memberikan implikasi kepada pihak berkaitan terutamanya murid, guru dan pihak sekolah. Terutamanya kaedah pengajaran dan pembelajaran menggunakan modul pengajaran dapat meningkatkan pencapaian akademik dan minat murid. Selain itu, kaedah penggunaan modul pengajaran dan pembelajaran dalam pengajaran juga dapat membantu guru menjadi pemudahcara kepada murid. Guru-guru boleh memberi panduan kepada murid tentang cara penggunaan modul 
pengajaran dan pembelajaran yang betul seiring dengan kemampuan pelajar. Guru-guru Pendidikan Kesenian disarankan membina modul pengajaran dan pembelajaran mengikut kemampuan murid. Pihak sekolah juga perlu menggalakkan guru-guru supaya membina dan menggunakan modul pengajaran dan pembelajaran sendiri dalam proses pengajaran dan pembelajaran. Selain itu, pihak sekolah boleh menganjurkan kursus dalam perkhidmatan (LDP) berkaitan pembinaan modul yang berkesan ke arah peningkatan pencapaian akademik dan minat murid. Modul pengajaran dan pembelajaran secara atas talian boleh dibangunkan agar koleksi modul-modul pengajaran dapat disimpan dan diakses oleh murid dan guru.

\section{Kesimpulan}

Keputusan kajian ini menunjukkan bahawa kaedah pengajaran Needham berpandukan Modul Pendidikan Kesenian terhadap pencapaian hasil kerja seni dan minat murid dalam mata pelajaran Pendidikan Kesenian memberikan kesan yang baik. Oleh itu, dapatlah dirumuskan bahawa penggunaan Modul Pendidikan Kesenian adalah sesuai digunakan sebagai salah satu strategi pengajaran dan pembelajaran Pendidikan Kesenian. Selain itu, prose pengajaran dan pembelajaran Pendidikan Kesenian dapat dilaksanakan dengan lebih teratur dan terancang. Pengajaran dan pembelajaran yang menggunakan kaedah pengajaran Needham berpandukan Modul Pendidikan Kesenian dapat membuka ruang kepada murid supaya dapat meneroka pembelajaran sendiri. Manakala guru pula dapat bertindak sebagai fasilitator yang mengawal pembelajaran murid. Kajian ini telah memberikan implikasi yang jelas terhadap pengajaran dan pembelajaran yang lebih menyeronokkan dan mendorong penglibatan aktif murid dalam mata pelajaran Pendidikan Kesenian. Akhir kata, pengkaji berharap agar kajian lanjutan dapat memberi sumbangan yang lebih berhubung dengan kaedah pengajaran Needham berpandukan Modul Pendidikan Kesenian dalam pengajaran dan pembelajaran Pendidikan Kesenian.

\section{Rujukan}

Altun, S. (2015). The effect of cooperative learning on students' achievement and views on the science and technology course. International Electronic Journal of Elementary Education, 7(3), 451-468.

Arihasnida Ariffin, Noridah Hasnan, Normah Zakaria, Siti Nur Kamariah Rubani \& Norhasyimah Hamzah. (2020). Pembangunan Bahan e-Pembelajaran Berasaskan Model Needham Lima Fasa bagi Topik Konkrit. Online Journal for TVET Practitioners. 5(2), 63-70.

https://doi.org/10.30880/ojtp.2020.05.02.008

Bavani Somasudram., \& Zamri Mahamod. (2017). Keberkesanan pembelajaran koperatif terhadap pencapaian dan motivasi murid sekolah menengah dalam pembelajaran Bahasa Melayu. Malay Language Education Journal, 7(1), 2180-4842.

Chan, K. W. (2014). Cooperative learning in a Hong Kong primary school: perceptions, problems and accommodation. Intercultural Education, 25(3), 216-228. https://doi.org/10.1080/14675986.2014.911805

Dick W, Carey L. (1996). The Systematic Design Of Instruction. (4th Ed.). New York: Harper Collins College Publishers.

Gull, F., \& Shehzad, S. (2015). Effects of Cooperative Learning on Students' Academic Achievement. Journal of Education and Learning (EduLearn), 9(3), 246. https://doi.org/10.11591/edulearn.v9i3.2071

Iyer, R. B. (2013). Relation between Cooperative Learning and Student Achievement. International Journal of Education and Information Studies., 3(1), 21-25.

Jasin, Z \& Shaari, A. S. (2012). Keberkesanan Model Konstruktivisme Lima Fasa Needham Dalam Pengajaran Komsas Bahasa Melayu. Jurnal Pendidikan Bahasa Melayu, 2(1), 79-92.

Kurikulum Standard Sekolah Rendah. (2018). Pendidikan Kesenian Tahun 4. Bahagian Pembangunan Kurikulum. Putrajaya: Kementerian Pendidikan Malaysia.

Malar, M. (2013). Kesan Kaedah STAD Terhadap Ketekalan Pengetahuan Sejarah Dan Kemahiran Sosial Murid Tingkatan Dua Malar. Seminar Pendidikan Sejarah Dan Geografi UMS, 2013, 29 30. 
Ocampo, R. O., \& Bascos-Ocampo, R. (2015). Effectiveness of Students' Team Achievement Division on Students' Attitude Towards Physics. Asia Pacific Journal of Multidisciplinary Research, 3(4), 112-117. Retrieved from http://www.apjmr.com/wp-content/uploads/2015/10/APJMR-20153.4.3.14.pdf

Pavlou, V., \& Kambouri, M. (2007). Puplis' Attitudes Towards Art Teaching in Primary School :

An Evaluation Tool. Studies in Educational Evaluation, 33, 282-301.

Robert E. Slavin. (2015). Cooperative learning in elementary schools. Education., 3-13. https://doi.org/10.1080/03004279.2015.963370

Syamsul Nor Azlan., M. (2011). The instructional material blended with Needham 5 phases strategy in teaching visual art education. Education and Educational Technology, 7-15.

Tran, V. D. (2014). The Effects of Cooperative Learning on the Academic Achievement and Knowledge Retention. International Journal of Higher Education, 3(2), 131-140. https://doi.org/10.5430/ijhe.v3n2p131

Tran, V.D. (2013). Effects of Student Teams Achievement Division (STAD) on Academic Achievement, and Attitudes of Grade 9th Secondary School Students towards Mathematics. International Journal of Sciences, 2(04), 5-15. Retrieved from http://www.ijsciences.com

Van Wyk, M. M. (2012). The effects of the STAD-Cooperative Learning Method on student achievement, attitude and motivation in economics education. Journal of Social Sciences, 33(2), 261-270.

Vaughan, W. (2002). Effects of cooperative learning on achievement and attitude among students of color. Journal of Educational Research, 95(6), 359-364. https://doi.org/10.1080/00220670209596610

Zainun Ismaon, Zanaton Iksan, \& Norziah Othman. (2013). Kesan Pembelajaran Koperatif Model STAD Ke Atas Sikap Terhadap Matematik. Jurnal Pendidikan Matematik, 1(1), 11-18. 